\title{
References:
}

1. Siham Abdoun A., Reem Alenizi. Formulation and evaluation of metronidazole lozenges for oral thrush. Journal of Innovations in Pharmaceutical and Biological Sciences. 2019. Vol. 6 (3). P. 5-10.

2. Salvatori C., Barchi L., Guzzo F., Gargari M. A comparative study of antibacterial and anti-inflammatory effects of mouthrinse containing tea tree oil. ORAL \& Implantology. 2017. Vol. 10(1). P. 59-70.

3. Nieto G., Ros G., Castillo J. Antioxidant and Antimicrobial Properties of Rosemary (Rosmarinus officinalis, L.): A Review. Medicines (Basel). 2018. V. 5 (3). 98.

4. Козименко Т. М., Дудченко Л. Г., Грабова Т. Ю., Пилипчук А. Б., Петріщева В. О. Застосування рослин класу хвойні у медицині. Родина соснові (огляд літератури). Фітотерапія. Часопис. 2014. № 2. С. 34-39.

5. Sentko A. Innovative low-glycaemic carbohydrates: an update. How a smart choice can contribute to a healthier life. Nutrafoods. 2013. Vol. 12. P. 127-135.

DOI https://doi.org/10.30525/978-9934-588-81-5-2.29

\section{STUDY OF THE FOAM-FORMING CAPACITY OF THE FINE OF DRY EXTRACT OF QUAWS AND DRY EGG WHITE FOR THE PREPARATION OF PHYTOCOCTAILS}

\author{
Chub O. V. \\ Candidate of Pharmaceutical Sciences, \\ Teaching Assistant at the Department of Cosmetology and Aromology \\ National University of Pharmacy \\ Zaporozhska S. M. \\ Candidate of Pharmaceutical Sciences, \\ Associate Professor at the Department of Commodity Science \\ National University of Pharmacy \\ Kharkiv, Ukraine
}

One of the forms of implementation of new medical technologies in phytotherapy is the development of new foam therapeutic systems as methods of delivery of medicinal compositions in the form of intragastric foam phytococktails. Foam systems provide contact with the mucous membrane of the gastrointestinal tract, providing deep penetration of medical drugs into all gastric folds, herewith the total surface area of the films increases 
significantly, and the bioavailability of medical drugs from such films expands considerably [2, p. 11].

Despite the fact that the experience of using foam cocktails is not long enough, the effectiveness of foam therapeutic systems of this type is unquestionable, however, the formulation of foam phytococktails is often not scientifically justified in terms of pharmacological effect, compatibility of formulation constituent, and, most importantly, the stability of the system in the presence of active oxygen. In addition, numerous guides to the preparation of phytococktails using special devices contain unprofessional explanations of the technological aspects of obtaining foamy cocktails from medicinal plant raw materials [5, p. 43].

As we have established, taking into account the data in the scientific literature [1, p. 5], there are requirements to the foams used in various sectors of the economy and the criteria of such requirements depend on the intended function of the foam masses [3, p. 21]. According to current data, the quality indicators of foams are studied by the following criteria:

- foam stability, characterized by a temporary factor;

- foam dispersion: the average diameter of the foam bubble;

- foam multiplicity: the ratio of the volume of the foam and the source liquid;

- foam density: mass of unit volume of the foam [4, p. 32].

It is known that when mixing different chemical compounds, that have surface-active properties, in some cases, both synergistic and antagonistic effects can be observed. These factors can have a stabilizing or destabilizing effect on the foaming ability of foaming agents [8, p. 12].

Manifestation of such effects can be established by the value of the mechanical properties of the surface layers and double-sided foam films, the foam volume, the foaming ability and the foam stability.

At the first stage, aqueous dispersions of compositions of dry extract of licorice root and dry egg white in different concentrations were obtained. Also, it was taken into account that the addition of licorice preparations in some cases may increase the therapeutic effect, as glycyrrhizinic acid, which is contained in it, has a pronounced anti-inflammatory, expectorant effect and, most importantly, corrects the taste, having a high degree of sweetness [7, p. 9].

For the study, we prepared samples of solutions of egg white and dry extract of licorice root in concentrations of 1.0 and $1.5 \% \%$ of each of the foaming agents. The concentration dependence of the dynamics of physicochemical processes at the gas-liquid phase separation was studied. 
One of the methods for determining the foaming ability is the Milser method [6, p. 33], according to which the foam is whipped for two minutes from a solution, which contains the foaming component in various concentrations, then the foam is left at room temperature for one minute. The foam formation process of the compositions of aqueous dispersions with natural and animal foaming agents was carried out by the method of whipping on the upper drive mixing device US-2000 at a speed of $1900 \mathrm{rpm}$ (dispersion time $-1 \mathrm{~min}$.).

In the obtained foam samples, the foaming ability, the foam formation rate and the effect of different amounts of dry extract of licorice root and dry egg white powder on the change of physicochemical properties of foams, as well as the stability of foams were observed. The stability of the foam was defined as the ratio of the size of the foam column after whipping to the size of the foam column after falling per minute [3, p. 21].

Analyzing the research results of visual observation of the fall of foams, we concluded that the foams formed by licorice extract were not dense, did not whip quickly, and during the 60-second experiment there was a drop of foam almost 4 times in samples with $1.0 \%$ content and 3 times - in samples with $1.5 \%$ content.

As for the egg white foam, the foam wasn't ruined for 60 seconds: the foam decrease by $5 \%$ was observed in samples with $1.0 \%$ egg white content. The foam of the sample with $1.5 \%$ content was very dense and the organoleptic characteristics did not meet the requirements of foam cocktails.

Afterwards, the samples with the content of $1.0 \%$ dry egg white and $1.5 \%$ dry extract of licorice root were chosen for further studies.

Then, for the purpose of determining the content of the foaming agent, the main characteristics of the foam masses were studied: dispersion, stability, kinetic stability and foams multiplicity [1, p. 7].

The dispersed composition was determined by the method of microphotography on a laboratory microscope Konus Academy (magnification 40 times). The average size of the gas phase was determined on the basis of the measurement of the size of 10 bubbles in the microscope eyepiece. Also, in the course of microscopic examination, the dynamics of fluid leakage from the Plateau tubules over time was observed and the «foam lifetime» was determined. According to the results of microscopic studies, the dispersions of bubbles of egg white foam solution $-1.8-2.3 \mathrm{~mm}$ and dry extract of licorice root $-1.0-1.8 \mathrm{~mm}$ were determined.

During the period of 200-300 seconds, the dynamics of fluid leakage from the Plateau tubules was observed and the «foam lifetime» was determined. As microscopic images of dispersion studies show, the dynamics of 
fluid flow from the Plateau tubules and the «foam lifetime» are more stable than egg white foam: during the observation time of 300 seconds, the foam wasn't ruined significantly [3, p. 11].

In the process of studying the leakage of fluid from the Plateau tubules (or «aging» of the foam masses) it was found that the full time of «foam lifetime» is within sufficient limits for taking of a cocktail. The process of the foam «aging» is accompanied by an increase in the degree of dispersion of the gas phase by several orders of magnitude; in addition, there is a change in its shape from round bubbles to polyhedral.

The results of microscopic examination suggested that the optimal content of dry egg white will be $1.0 \%$ as a foaming agent for the oxygen cocktail.

The egg white foam was denser than the dry licorice extract foam, which is desirable in an oxygen cocktail. This foam from an oxygen cocktail can be taken with spoons. This practice exists for more convenient use of cocktails [8, p. 31].

The kinetic stability of the foam according to the stability assessment indicator was determined as the ratio of the volume of the foam column 10 minutes after the formation of the foam to the initial volume (\%).

Conclusion. According to the results of the study of physicochemical characteristics of foams, it was found that:

- the dispersion of the gas phase of foams based on dry extract of licorice root is less than foams based on egg white;

- «the bubble lifetime» is from $80 \mathrm{~s}$ (dry extract of licorice root) to 300 s (dry egg white);

- the value of kinetic stability is greater in egg white foam.

On the basis of comparative experimental data on the quality indicator of foam systems in the composition of the cocktail as a foaming agent, the dry egg white at a concentration of $1.0 \%$ was chosen.

Our findings were used to form foam systems with specified therapeutic properties, namely in order to saturate with the therapeutic gas component - oxygen.

\section{References:}

1. Береговых, В. В., Касьянова О. В., Лопатин П. В. Анализ текущей ситуации регулирования ценообразования на лекарственные средства в России. Фармащия. 2002. Т. 51, № 3. С. 17-19.

2. Гусакова, Е. В. Новые подходы к организации восстановительного лечения. Актуальные проблемы восстановительной медицины, 
курортологии и физиотерапии: материалы междунар. конгр. «Здравница-2004». Кисловодск: 2004, СПб. С. 98.

3. Давыдова, О. Б. Новые аспекты медицинской курортологии. Актуальные проблемы восстановительной медицины, курортологии и физиотерапии: материалы междунар. конгр. «Здравница-2004». Кисловодск: 2004, СПб. С. 102.

4. Жогло, Ф. А. Пенообразователи на основе жиросахаров. Москва. Легкая промышленность, 2007. 343 с.

5. Заноздра, Н. С., Нужный Д. А., Крищук А. А. Применение кислородной смеси с лечебной целью. Врачебное дело. 2008. № 8. C. $13-15$.

6. Иванец, Г. Е., Коршиков Ю. А., Ратников С. А. Анализ различных схем движения материальных потоков в центробежных смесителях непрерывного действия. Деп. рук. Указатель ВИНИТИ Депонированные рукописи. Москва. 2008. № 3781 - В99.

7. Колесникова, Л. І., Колесніков С. І. Процеси перекисного окислення ліпідів в патогенезі ускладнень вагітності. 1 Росс. конгрес $з$ патофізіологіï. Тез. доп. Москва. 2013. 198 с.

8. Коростелева Т. М. Организация летней оздоровительной работи с детьми в дошкольных учреждениях: методические рекомендации. Минск : Министерство образования и науки, Министерство здравоохранения, 2002. 